\title{
Study of Dormancy Type and Effect of Different Pre-Sowing Treatments on Seed Germination of Bladder-Senna (Colutea bohsei Boiss.) in Laboratory Conditions
}

\author{
Ahmad BEIKMOHAMMADI*, Ali TEHRANIFAR, Hossein NEMATI, Mahmoud SHOOR
}

Ferdowsi University of Mashhad, Agriculture Faculty, Horticultural Science Department, Azadi Square, Mashhad,Iran; ah.beik@yahoo.com (*correspondingauthor)

\begin{abstract}
The present study was conducted in order to evaluate the existence and type of the dormancy and effects of different dormancy breaking treatments on seed germination of Colutea bubsei Boiss. (Fabaceae) as one of the Iran native plants, arid-land and ornamental shrub with ability of usage in the urban landscape design. The experiment was performed with 15 treatments and 3 replications in a completely randomized design. Seeds were subjected to different treatments including various levels of $\mathrm{GA}_{3}$, concentrated $(98 \%) \mathrm{H}_{2} \mathrm{SO}_{4}$ cold stratification (CS), soaking with tab water, floating in hot water $\left(100^{\circ} \mathrm{C}\right)$ followed by continual cooling for $24 \mathrm{hr}$ in the same water and combined treatments. Afterwards seeds were sown in laboratory conditions to determine the factors' effects on germination percentage (GP), germination rate (GR), root and shoot length of Colutea bohsei seeds. All of these treatments, except for GA 30 and $500 \mathrm{ppm})$, increased the percentage and rate of the seed germination. Maximum germination percentage (66.25\%) and rate (14.9 seeds per day) in 7 days was obtained at concentrated $(98 \%) \mathrm{H}_{2} \mathrm{SO}_{4}(15 \mathrm{~min})$. Maximum root and shoot length was observed at concentrated $(98 \%) \mathrm{H}_{2} \mathrm{SO}_{4}(15 \mathrm{~min})$ plus $\mathrm{GA}_{3}(100 \mathrm{ppm}, 24 \mathrm{hr})$. Use of GA 3 (100 ppm) in $24 \mathrm{hr}$ after $\mathrm{H}_{2} \mathrm{SO}_{4}$ increased the germination rate and shoot length but this additive effect was not significant.
\end{abstract}

Keywords: arid-land, drought tolerant, landscape design, native plant, ornamental shrub

\section{Introduction}

The Colutea L. (bladder-sennas) genus includes about 26 species of deciduous shrubs and small trees with a distribution ranging from the Mediterranean region and South-Eastern Europe and North-West Africa (Browicz, 1963). Colutea bohsei Boiss. (Fabaceae) is a fast-growing shrub up to $3 \mathrm{~m}$ height, with flexible and gray stems and often grows at the altitudes of Alborz Mountains. The global distribution of this shrub is Iran and Turkmenistan; and its distribution in the Iran provinces is Golestan, Mazandaran, Azarbaijan, Khorasan, Semnan and Tehran. From botanical point of view, it bears branchy leaves composed of small and bright green leaflets, yellow flowers and fruit is a pod-shaped balloon (Mozaffarian, 2005). It is a drought-tolerant plant occurring in rocky and steep landscapes and is known as an important species in preventing soil erosion and functional for landscape design. Colutea species are cultivated in temperate climates primarily for ornamental purposes (Krüsmann, 1984; Rudolf, 1974). Colutea L. species domestication is limited by the low germination rates and high susceptibility of the seeds to fungal attack (Aguinagalde et al., 1990).

Seeds of many woody plant species cannot germinate even if they are sown under optimal moisture, oxygen and soil conditions (Olmez et al., 2008). This problem is called dormancy and its causes are a hard and impermeable seed coat, immature or dormant embryo, absence of endosperm, or thick, fleshy seed cover (ISTA, 1993). There is great deal of variation in germination ability of seeds even within the same species. Poulsen (1996) reported that dormancy among and within seed lots, of the same species, varied with provenance, crop year, and individual trees.

There are various germination obstacles in Colutea seeds (Dirr and Heuser, 1987; Dirr, 1990; Olmez et al., 2007, 2008) resulting in propagation difficulties (Heit, 1967; Piotto et al., 2003). There have been few studies to determine different methods and techniques to overcome seed dormancy in Colutea species. Generally, pretreatments such as submersion in hot water, mechanical or chemical scarification, and hot aeration are used for seed coat dormancy while the cold and warm stratifications are usually applied to dormancy caused by restrictions at the embryo level (Landis et al., 1996). Among these methods and techniques, especially cold stratification, submersion in concentrated $\mathrm{H}_{2} \mathrm{SO}_{4}$, and steeping seeds in hot water $\left(88-100^{\circ} \mathrm{C}\right)$, followed by $24 \mathrm{hr}$ chilling, are well-known and used to increase germination percentage of Colutea seeds (Dirr and Heuser, 1987; Piotto et al., 2003; Olmez et al., 2007).

The aim of this study was to investigate the dormancy type and influence of various dormancy-breaking treatments (submersion in tap water, submersion in hot water, submersion in $\mathrm{H}_{2} \mathrm{SO}_{4}, \mathrm{GA}_{3}$, cold stratification and com- 
bined this treatments) on germination of Colutea bohsei seeds, sown in laboratory conditions.

\section{Materials and methods}

Ripe fruits were collected in mid-summer, 2010 from altitudes $(1500 \mathrm{~m})$ of Shahrud (Kalpush) provenance with geographical co-ordinates: latitude $37^{\circ} 13^{\prime}$ North and longitude $55^{\circ} 48^{\prime}$ East with relatively warm summers and cold winters located in the North part of Iran. The seeds were separated from the fruit and stored at $5 \pm 1^{\circ} \mathrm{C}$ in plastic bags in the refrigerator and then the following pre-sowing treatments were applied to determine their effects on germination percentage (GP), germination rate (GR), root and shoot length of Colutea bohsei seeds:

1-Floating in tap water $\left(20 \pm 1^{\circ} \mathrm{C}\right)$ for $24 \mathrm{~h}$;

2-Floating in hot water $\left(100^{\circ} \mathrm{C}\right)$ followed by continual cooling for $24 \mathrm{~h}$, in the same water;

3-Cold stratification (CS) for 15 and 30 days in $\left(5 \pm 1^{\circ} \mathrm{C}\right)$ into refrigerator;

4-Submersion in concentrated $(98 \%) \mathrm{H}_{2} \mathrm{SO}_{4}$ for 5,15 and $30 \mathrm{~min}$;

5-Floating in $\mathrm{GA}_{3}(100,250$, and $500 \mathrm{ppm})$ for $24 \mathrm{~h}$;

6-Submersion in concentrated (98\%) $\mathrm{H}_{2} \mathrm{SO}_{4}$ for 15 $\mathrm{min}$, and then floating in $\mathrm{GA}_{3}(100,250$, and $500 \mathrm{ppm})$ for $24 \mathrm{~h}$;

7-Submersion in concentrated (98\%) $\mathrm{H}_{2} \mathrm{SO}_{4}$ for 30 $\mathrm{min}$, and then floating in $\mathrm{GA}_{3}(100 \mathrm{ppm})$ for $24 \mathrm{~h}$;

8-Control (no treatment).

Seeds were stratified by putting layers of moistened sand and seeds on top of each other into refrigerator with mean temperature $5 \pm 1^{\circ} \mathrm{C}$. Since there was a risk for some of the seeds to be mixed with the sand, because of their small size, linen cloth was placed between the sand and the seeds. The moisture of the sand and the seeds were checked continuously to avoid drying, heating and poor aeration.

Twenty seeds were sown on wet filter paper in each glass petri-dish, under laboratory conditions (mean relative humidity $50 \%$ and mean ambient day temperature of $23 \pm 2^{\circ} \mathrm{C}$ and $17 \pm 2^{\circ} \mathrm{C}$ night temperature) in Ferdowsi University of Mashhad in the winter of 2011. Visible radicle growth was used to define germination. Seeds germination recorded daily; continued until no further germination occurred for 5 days; and recording duration of germination was 15 days. Germination percentage and germination rate was calculated using Maguire's equations (1962):

$$
\mathrm{GP}=100\left(\mathrm{~N}_{\mathrm{G}} / \mathrm{N}_{\mathrm{T}}\right)
$$

where $\mathrm{N}_{\mathrm{G}}$ is the number of germinated seeds and $\mathrm{N}_{\mathrm{T}}$ is the total number of seeds.
$\mathrm{GR}=\mathrm{n} 1 / \mathrm{t} 1+\mathrm{n} 2 / \mathrm{t} 2+\ldots+\mathrm{n} 15 / \mathrm{t} 15$

where $n 1, n 2, \ldots, n 15$ are the number of germinated seeds at times $\mathrm{t} 1, \mathrm{t} 2, \ldots, \mathrm{t} 15$ (in days).

For the study of the treatments' effect on root and shoot length, 15 normal seedlings were measured from each replication and expressed in centimeter in the final day of experiment. The experiment was conducted in randomized completely design with 15 treatments and three replications (60 seeds per replication) for each treatment. Data from the treatments were analyzed using SAS statistical software. The LSD test was used for treatment mean comparison $(\alpha=0.05)$.

\section{Results and discussion}

Experiment analyse of variance indicates that effects of various treatments on germination percentage (GP), germination rate (GR), root and shoot length of Colutea bohsei seeds were significant $(\alpha=0.01)$ (Tab. 1).

Statistical analyses showed that the highest germination percentages $(66.2 \%)$ were obtained in seeds submersed in $\mathrm{H}_{2} \mathrm{SO}_{4}$ for $15 \mathrm{~min}$ in laboratory conditions (Tab. 2). These results may indicate that the seeds of this shrub have a kind of dormancy that makes necessary their germination's stimulation by removing the hard cover of seeds. Because the $\mathrm{H}_{2} \mathrm{SO}_{4}$ treatments are used in abrasion and softening the seed coat, it can be stated that the dormancy type of $C$. bohsei seeds is a physical dormancy and is pertaining to the seed coat. Similar findings were reported by Dirr (1990), who found that soaking Colutea seeds in $\mathrm{H}_{2} \mathrm{SO}_{4}$ for 30$60 \mathrm{~min}$ resulted in good germination. According to Dirr (1990), some Colutea seeds did not germinate easily unless the impermeable seed coat was ruptured by mechanical or chemical scarification. Olmez et al. (2008) stated that soaking $C$. armena seeds in $\mathrm{H}_{2} \mathrm{SO}_{4}$ for $30 \mathrm{~min}$ and sown in the greenhouse resulted in good GP value (77.2\%). In addition, Olmez et al. (2007) reported that scarification of $C$. armena seeds by soaking in $\mathrm{H}_{2} \mathrm{SO}_{4}$ for $30 \mathrm{~min}$ and sown under laboratory conditions gave high GP (82.8\%) and a short time to maximum GR (7 days). Ren and Tao (2004) stated that speed and percent germination of the Calligonum species can be greatly increased by mechanical scarification or acid treatments.

The lowest average GP (7.5\%) was determined at control seeds and those floating in $\mathrm{GA}_{3}$ (250 and $500 \mathrm{ppm}$ ) for $24 \mathrm{hr}$, which were sown under laboratory conditions (Tab. 2). Dirr and Heuser (1987) reported that untreated $\mathrm{Co}$ lutea seeds could be sown in autumn, but scarification was required for spring-sowing. Among combined treatments,

Tab. 1. Summary of analysis of variance for measured parameters in Colutea bubsei Boiss. seeds

\begin{tabular}{cccccc}
\hline \multicolumn{5}{c}{ Mean square } \\
\hline Source of variation & df & Germination rate (GR) & Germination percentage (GP) & Root length & Shoot length \\
\hline Factor & 14 & $129^{* *}$ & $1850^{* *}$ & $1.73^{* *}$ & $9^{* *}$ \\
Error & 45 & 4 & 58 & 0.05 & 0.06 \\
\hline
\end{tabular}

** Significant at $p<0.01 ; \mathrm{df}$ : degrees of freedom 
114

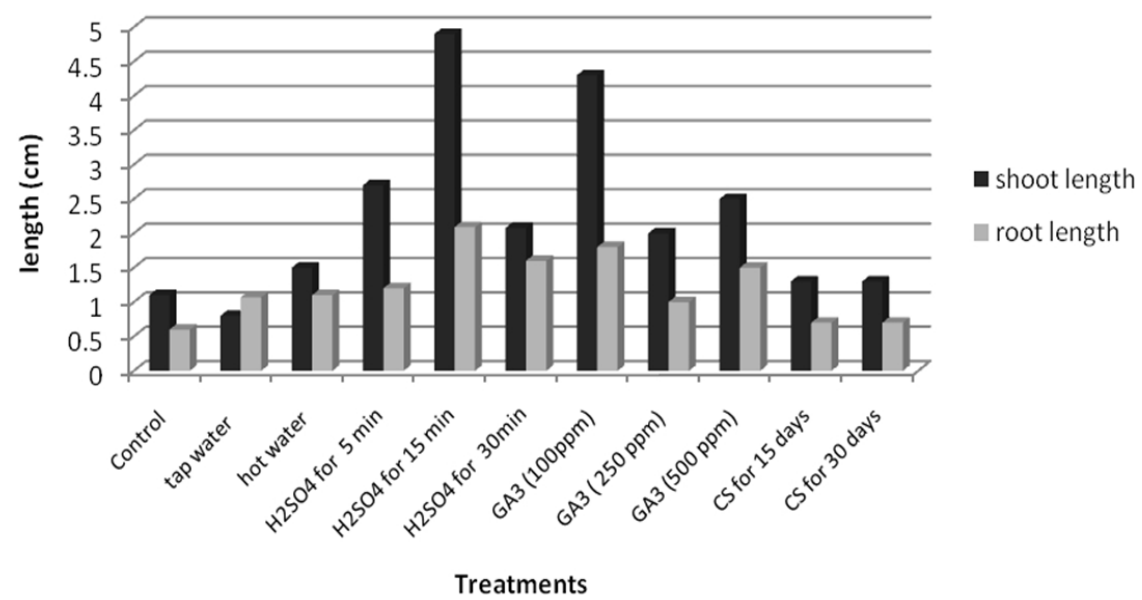

Fig. 1. Effects of various treatments on root and shoot length of Colutea bohsei seeds in laboratory conditions in the end of experiment

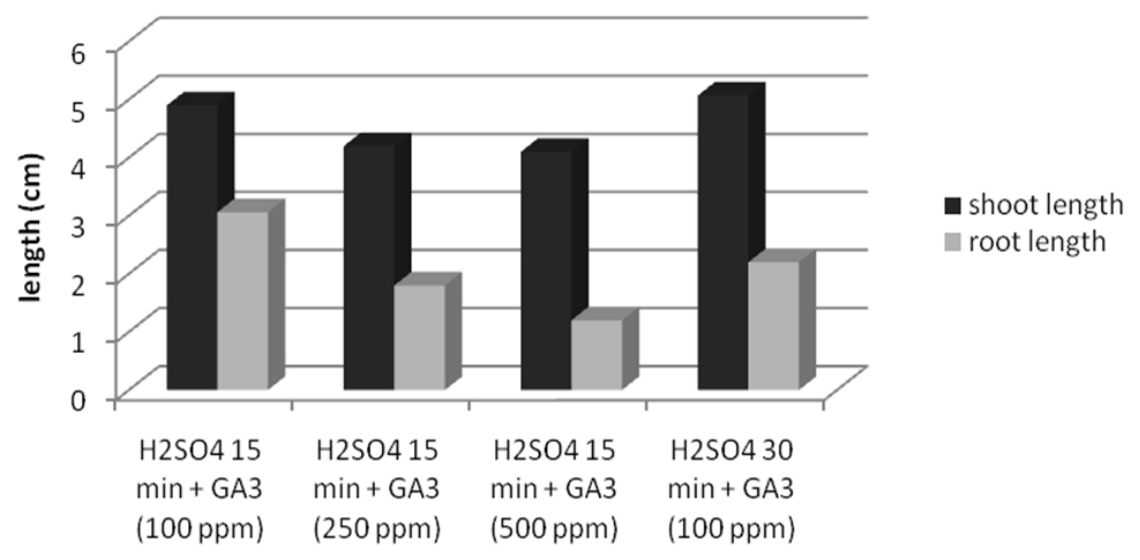

treatments

Fig. 2. Effect of combined dormancy breaking treatments on shoot and root length of Colutea bohsei seeds in laboratory conditions in the end of experiment

Tab. 2. Effect of various dormancy breaking treatments on germination percentage and germination rate of Colutea bohsei Boiss. seeds in laboratory conditions

\begin{tabular}{|c|c|c|}
\hline Treatments & $\begin{array}{c}\text { Germination } \\
\text { percentage (\%) }\end{array}$ & $\begin{array}{c}\text { Germination rate } \\
\text { (in day) }\end{array}$ \\
\hline Control (no treatment) & $7.5 \mathrm{~h}$ & $1.5 \mathrm{gh}$ \\
\hline Floating in tap water $\left(20 \pm 1^{\circ} \mathrm{C}\right)$ for $24 \mathrm{~h}$, & $22.5 \mathrm{f}$ & $4.1 \mathrm{fg}$ \\
\hline Floating in hot water $\left(100^{\circ} \mathrm{C}\right)$ followed by continual cooling for $24 \mathrm{~h}$, in the same water, & $18.7 \mathrm{fg}$ & $2.3 \mathrm{gh}$ \\
\hline Submersion in concentrated $(98 \%) \mathrm{H}_{2} \mathrm{SO}_{4}(5 \mathrm{~min})$ & $38.7 \mathrm{dc}$ & $6 \mathrm{ef}$ \\
\hline Submersion in concentrated $(98 \%) \mathrm{H}_{2} \mathrm{SO}_{4}(15 \mathrm{~min})$ & $66.2 \mathrm{a}$ & $14.9 \mathrm{ab}$ \\
\hline Submersion in concentrated $(98 \%) \mathrm{H}_{2} \mathrm{SO}_{4}(30 \mathrm{~min})$ & $53.7 \mathrm{~b}$ & $10.2 \mathrm{~d}$ \\
\hline Floating in GA3 (100 ppm) for $24 \mathrm{~h}$ & 30 de & $8.7 \mathrm{de}$ \\
\hline Floating in GA3 (250 ppm) for $24 \mathrm{~h}$, & $7.5 \mathrm{~h}$ & $0.8 \mathrm{~h}$ \\
\hline Floating in GA3 (500 ppm) for $24 \mathrm{~h}$, & $7.5 \mathrm{~h}$ & $0.4 \mathrm{~h}$ \\
\hline Cold stratification $(\mathrm{CS})$ for 15 days in $\left(5 \pm 1^{\circ} \mathrm{C}\right)$ & $11.2 \mathrm{gh}$ & $2.8 \mathrm{gh}$ \\
\hline Cold stratification $(\mathrm{CS})$ for 30 days in $\left(5 \pm 1^{\circ} \mathrm{C}\right)$ & $21.2 \mathrm{fg}$ & $2.6 \mathrm{gh}$ \\
\hline Submersion in concentrated $(98 \%) \mathrm{H}_{2} \mathrm{SO}_{4}$ for $15 \mathrm{~min}+(\mathrm{GA} 100 \mathrm{ppm})$ for $24 \mathrm{~h}$ & $57.5 \mathrm{ab}$ & $13.3 \mathrm{~b}$ \\
\hline Submersion in concentrated $(98 \%) \mathrm{H}_{2} \mathrm{SO}_{4}$ for $15 \mathrm{~min}+(\mathrm{GA} 250 \mathrm{ppm})$ for $24 \mathrm{~h}$ & $66.2 \mathrm{a}$ & $13.2 \mathrm{bc}$ \\
\hline Submersion in concentrated $(98 \%) \mathrm{H}_{2} \mathrm{SO}_{4}$ for $15 \mathrm{~min}+(\mathrm{GA} 500 \mathrm{ppm})$ for $24 \mathrm{~h}$ & $48.7 \mathrm{bc}$ & $10.4 \mathrm{~cd}$ \\
\hline Submersion in concentrated $(98 \%) \mathrm{H}_{2} \mathrm{SO}_{4}$ for $30 \mathrm{~min}+(\mathrm{GA} 100 \mathrm{ppm})$ for $24 \mathrm{~h}$ & $66.2 \mathrm{a}$ & $17.4 \mathrm{a}$ \\
\hline
\end{tabular}

Note: Means in column with the same letter are not significantly different (LSD test, $p<0.05)$ 

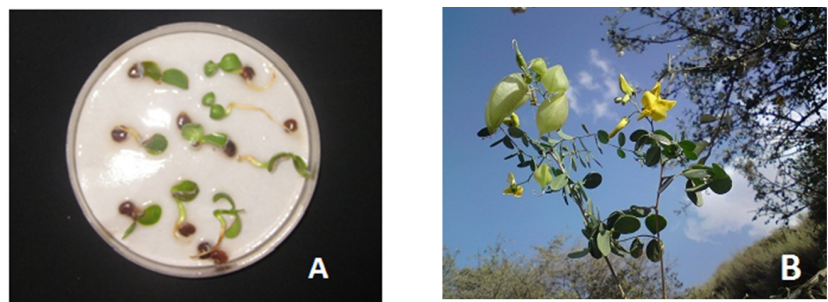

Fig. 3. Seeds germination in laboratory conditions (A) and mature shrub of Colutea bohsei Boiss. in habitat (B)

submersion in concentrated $(98 \%) \mathrm{H}_{2} \mathrm{SO}_{4}$ for $30 \mathrm{~min}$ and then $\left(\mathrm{GA}_{3} 100 \mathrm{ppm} 24 \mathrm{hr}\right)$ resulted the best germination percentage (66.2\%) under laboratory conditions (Tab. 2). Similar results by Nadjafi et al. (2006), showed that acid scarification by $\mathrm{H}_{2} \mathrm{SO}_{4}(75 \% \mathrm{v} / \mathrm{v})$, for 5 and 10 min with $\mathrm{GA}_{3}(1500 \mathrm{ppm}, 48 \mathrm{hr}$ ), broke dormancy and induced $31.9 \%$ and $34.1 \%$ germination of T. polium, respectively. The best germination rates for laboratory conditions were 17.4 seeds in days which were determined in seeds soaked in concentrated $(98 \%) \mathrm{H}_{2} \mathrm{SO}_{4}$ for $30 \mathrm{~min}$ plus floating in $\mathrm{GA}_{3}$ (100 ppm) for $24 \mathrm{hr}$ (Tab. 2).

The highest root and shoot length was 3.6 and $4.9 \mathrm{~cm}$ respectively, which were observed in seed soaked (98\%) $\mathrm{H}_{2} \mathrm{SO}_{4}$ for 15 min plus floating in $\mathrm{GA}_{3}(100 \mathrm{ppm})$ for $24 \mathrm{hr}$. Using of $\mathrm{GA}_{3}$ (100 ppm, $24 \mathrm{hr}$ ) after $\mathrm{H}_{2} \mathrm{SO}_{4}$, increased germination rate and shoot length but this additive effect was not significant. In combined treatments $\left(\mathrm{H}_{2} \mathrm{SO}_{4}+\mathrm{GA}_{3}\right)$ with increasing $\mathrm{GA}_{3}$ concentration, shoot and root length decreased (Fig. 2).

\section{Conclusions}

Among all the pre-sowing treatments applied, soaking in $\mathrm{H}_{2} \mathrm{SO}_{4}$ for 15 min resulted the highest $\mathrm{GP}(66.2 \%)$ and GR (14.9\%) in the shortest time to maximum GR (8 days) with good root and shoot length that was 2.09 and $4.9 \mathrm{~cm}$ respectively. These results may indicate that the seeds of this shrub have a kind of dormancy that indicates their germination's stimulation by removing the hard cover of seeds. Therefore, according to these results pre-treatment by submersion in $\mathrm{H}_{2} \mathrm{SO}_{4}$ for $15 \mathrm{~min}$ can be used to overcome dormancy of the C. bohsei Boiss. seeds.

\section{Acknowledgements}

We are thankful of financial support for Ferdowsi University of Mashhad.

\section{References}

Aguinagalde I, Perezgarcia F, Gonzalez A (1990). Flavonoids in seed coats of 2 Colutea species-ecophysiological aspects. J Basic Microbiol 30(8):547-553.

Browicz K (1963). The genus Colutea L. monograph. Monographie Bot 14:136.

Dirr MA (1990). Manual of woody landscape plants, their identification, ornamental characteristics, culture, propagation and uses. Stipes Publishing Company, Champaign, IL.

Dirr MA, Heuser CW (1987). The reference manual of woody plant propagation from seed to tissue culture. Varsity Pres, Athens.

Heit CE (1967). Propagation from seed, successful propagation of six hardseeded group species. Am Nurseryman 125(12):10-12.

ISTA (1993). Rules for testing seeds. Seed Sci Technol 21:1259.

Krüsmann G (1984). Manual of cultivated broad-leaved trees and shrubs. Vol. 1, Timber Pres, Beaverton, USA.

Landis TD, Barthell A, Loucks D (1996). Seed treatments to overcome dormancy. Forest Nursery Notes, United States, Department of Agriculture, Forest Services, USA, 9-12 p.

Maguire JD (1962). Speed of germination-aid in selection and evaluation for seedling emergence and vigor. Crop Sci 2:176-177.

Mozaffarian V (2005). Iran trees and shrubs, Farhang Maaser Press.

Nadjafi F, Bannayan M, Tabrizi L, Rastgoo M (2006). Seed germination and dormancy breaking techniques for Ferula gummosa and Teucrium polium. J Arid Environ 64:542-547.

Olmez Z, Gokturk A, Temel F (2007). Effects of cold stratification, $\mathrm{H}_{2} \mathrm{SO}_{4}$, submersion in hot and tap water pretreatments on germination of Bladder-Senna (Colutea armena Boiss. \& Huet.) seeds. Seed Sci Technol 35(2):266271.

Olmez Z, Gokturk A, Karasah B, Yilmaz H (2008). Effects of cold stratification and $\mathrm{H}_{2} \mathrm{SO}_{4}$ pretreatments on germination of three provenances of smoke-tree (Cotinus coggygria Scop.) seeds in greenhouse and laboratory conditions. Afr J Biotechnol 8(19):4964-4968.

Piotto B, Bartolini G, Bussotti F, Asensio A, García C, Chessa I, Ciccarese C, Ciccarese L, Crosti R, Cullum FJ, Noi AD, García P, Lambardi M, Lisci M, Lucci S, Melini S, Carlos J, Reinoso M, MurrancaS, Nieddu G, Pacini E, Pagni G, Patumi M, Garcia FP,Piccini C, Rossetto M, Tranne G, Tylkowski $\mathrm{T}$ (2003). Fact sheets on the propagation of Mediterranean trees and shrubs from seed, 11-51 p. In: Piotto B, Noi AD (Eds.). Italy, Seed Propagation of Mediterranean Trees and Shrubs APAT, I.G.E.R.

Poulsen K (1996). Case study: Neem (Azadirachta indica A. Juss.) Seed research, 14-22 p. In: Ouedraogos AS, Poulsen K, Stubsgaard F (Eds.). Proc an International Workshop on Improved Methods for Handling and Storage of Intermediate/Recalcitrant, Humlebaek, Denmark.

Ren J, Tao L (2004). Effects of different pre-sowing seed treatments on germination of 10 Calligonum species. Forest Ecol Manage 195:291-300.

Rudolf PO (1974). Colutea arborescens L. (Bladder-senna). In: Schopmeyer CS (Ed.). Seeds of Woody Plants in the United States, Agric. Handbook 450, USDA Forest Service, Washington DC, USA. 